\title{
REALISASI PRINSIP KERJASAMA DALAM SEBUAH INTERAKSI
}

\author{
oleh: M. Jazeri \\ STAIN Tulungagung
}

\begin{abstract}
This article describes the use and the violation of principles of cooperation or maxims. The maxims are used for some purposes. The maxim of quantity is used to express information clearly, to ask for help, and to avoid misunderstanding. The maxim of quality is used to express true information, to argue an opinion, and to make a conclusion. The maxim of relevance is used to find out true information and to give true information. The maxim of manner is used to express information clearly and to avoid misunderstanding.

The violations of the maxims can be done by means of direct violation, opting out, clashing, and flouting. Such violations have some functions. The maxim of quality is violated to raise a comic effect, to hide an intention, to flatter, and to hide embarrassment. The maxim of relevance is violated to raise a conversational implicature and to raise a comic effect. The maxim of manner is violated to hide embarrassment, to raise a comic effect, and to raise a conversational implicature.
\end{abstract}

Keywords: maxims of cooperation, maxim violation

\section{A. PENDAHULUAN}

Sebagai makhluk sosial, manusia tidak mungkin mampu memenuhi segala kebutuhan hidupnya sendirian. Ia membutuhkan kehadiran orang lain untuk membuat hidupnya bermakna. Di sinilah diperlukan interaksi antarmanusia. Agar tujuan interaksi dapat tercapai dengan baik, para peserta interaksi perlu memiliki pengetahuan komunikatif yang terdiri atas pengetahuan linguistik, pengetahuan interaksi, dan pengetahuan kebudayaan (Ibrahim, 1993). Demikian juga, agar pesan dapat sampai secara efektif dan efisien, Rahardi (dalam Jumadi, 2001) menyarankan agar peserta interaksi mempertimbangkan (1) prinsip kejelasan, (2) prinsip kepadatan, dan (3) prinsip kelangsungan. Prinsip kejelasan menuntut agar peserta tutur menyampaikan informasi secara jelas, tidak ambigu. Prinsip kepadatan menuntut paserta tutur agar menyampaikan informasi secara singkat dan padat. Sedangkan prinsip kelangsungan menuntut agar peserta tutur menyampaikan informasi secara langsung, tidak berbelit-belit.

Dalam berinteraksi, manusia menggunakan bahasa dalam bertutur. Agar tuturan mudah dipahami oleh mitra tuturnya, manusia menggunakan kaidah bertutur. Berkenaan dengan kaidah tindak tutur, Grice (1975) merumuskan kaidah bertutur prinsip kerjasama (selanjutnya disebut PKS). PKS merupakan kaidah bertutur yang berisi sejumlah tuntunan bagaimana seharusnya seseorang bertutur. PKS dirumuskan sebagai berikut, 'Buatlah sumbangan informasi Anda seinformatif yang dibutuhkan pada saat berbicara, berdasarkan tujuan percakapan yang disepakati atau arah percakapan yang sedang diikuti'.

Secara mendasar, dalam berinteraksi antara penutur dan mitra tutur sama-sama menyadari bahwa ada kaidah-kaidah yang mengatur tindakannya, penggunaan bahasanya, dan interpretasi-interpretasinya. Agar interaksi 
mencapai tujuannya, setiap penutur bertanggung jawab atas penggunaan kaidahkaidah tersebut. Levinson (1992) menyatakan bahwa PKS dengan sejumlah maksimnya mengkhususkan pada apa yang dapat diperbuat oleh peserta tutur untuk bertutur dengan cara yang efisien, rasional, dan kooperatif. Ketika menyampaikan informasi, antara penutur dan mitra tutur harus bertutur dengan tulus, relevan, dan jelas.

\section{B. INTERAKSI: KOMPONEN DAN FUNGSINYA}

Secara etimologis interaksi berasal dari bahasa latin inter yang berarti antara dan agree yang berarti berbuat. Jadi, interaksi berarti saling berbuat. Secara epistemologis, River (1987) mengatakan bahwa interaksi adalah kegiatan yang melibatkan pengiriman pesan, penerimaan pesan, dan konteks. Allen (1975) mengemukakan interaksi sebagai proses verbal dan nonverbal yang bersifat timbal balik yang diorganisisasi dengan suatu pola tindakan yang bermakna antara satu individu dengan individu lainnya. Jadi, pada dasarnya interaksi merupakan bentuk kerjasama antarindividu yang dilakukan dengan media verbal, nonverbal, atau gabungan keduanya.

Sebuah interaksi melibatkan beberapa komponen. Hymes (1973) menjelaskan ada enam belas komponen interaksi. Komponenkomponen tersebut diringkas menjadi delapan yang diakronimkan dengan SPEAKING, yakni setting (latar), participant (peserta), ends (tujuan), act sequences (urutan tutur), key (kunci), instrument (alat/saluran), norms (kaidah), dan genre (genre).

Rofi'udin (1990) menyederhanakan komponen-komponen interaksi menjadi (1) media yang digunakan, (2) pelaku interaksi, dan (3) konteks yang melatarinya. Media yang dimaksud adalah media bahasa, baik verbal maupun nonverbal. Media verbal antara lain pernyataan, perintah, dan pertanyaan, sedangkan nonverbal antara lain gerak-gerik dan ekspresi wajah (mimik). Konteks dapat berupa fisik maupun nonfisik. Konteks fisik berupa tempat, waktu dan situasi, sedangkan konteks nonfisik, berupa budaya, norma serta konvesi-konvensi sosial.

Adanya berbagai komponen dalam kegiatan interaksi, membuat interaksi memiliki bentuk yang bermacam-macam, misalnya: interaksi dalam dunia usaha, pengadilan, dokter-pasien, jual-beli, kelas, sekolah, keluarga, dan masyarakat. Setiap jenis interaksi memiliki kekhasannya sendiri-sendiri, baik dalam hal penggunaan media, kaidah bertutur, norma interpretasi, maupun struktur interaksi.

Interaksi merupakan kegiatan komunikasi, karena itu fungsi interaksi sama dengan fungsi komunikasi. Saville-Troike (1982) menjelaskan fungsi komunikasi dari sudut etnografi komunikasi. Dalam pandangan ini, fungsi komunikasi dibedakan ke dalam fungsi komunikasi tingkat sosial, fungsi komunikasi tingkat kelompok, dan fungsi komunikasi tingkat individu. Pada tingkat sosial, komunikasi berfungsi sebagai peningkat persatuan dan kesatuan sosial. Pada tingkat kelompok dan individu, komunikasi berfungsi untuk (1) mengungkapkan persaan dan emosi (expressive), (2) memerintah atau meminta bantuan (directives), (3) mengetahui benar tidaknya suatu proposisi (referensial), (4) mengungkapkan rasa keindahan (poetic and aesthetic), (5) menyatakan rasa phatik, empatik, simpatik, dan solidaritas, dan (6) fungsi yang mengacu pada komunikasi itu sendiri (metalingual).

Searle (1969) menjelaskan fungsi komunikasi dari sudut tindak berbahasa (speech acts). Menurutnya, komunikasi memiliki lima fungsi, yakni representatif, direktif, komisif, ekspresif, dan deklaratif. Tindak representatif digunakan untuk menyatakan sesuatu, neyampaikan fakta, penjelasan, atau laporan suatu kejadian. Tidak direktif digunakan untuk mengekspresikan maksud penutur sehingga dapat dijadikan alasan mitra tutur untuk melakukan sesuatu. Tindak komisif digunakan untuk melibatkan penutur pada beberapa tindakan yang akan datang, misalnya menjanjikan, menawarkan, bersumpah, dan memanjatkan do'a. Tindak ekspresif berfungsi untuk mengungkapkan atau 
memberitahukan sikap psikologis penutur, misalnya mengucapkan terimakasih, memaafkan, menyalahkan, memuji, dan menyatakan belasungkawa. Tindak deklaratif berisi korespondensi yang baik antara isi proposional dengan realitas, misalnya memecat, membebaskan, membabtis, dan memberi nama.

\section{PRINSIP KERJASAMA DAN MAKSIM-MAKSIMNYA}

Grice (1991:309) menyatakan bahwa percakapan akan mengarah pada penyamaan unsur-unsur pada transaksi kerjasama yang semula berbeda. Penyamaan tersebut dilakukan dengan jalan: (1) menyamakan jangka tujuan pendek, meskipun tujuan akhirnya berbeda atau bahkan bertentangan, (2) menyatukan sumbangan partisipasi sehingga penutur dan mitra tutur saling membutuhkan, dan (3) mengusahan agar penutur dan mitra tutur mempunyai pengertian bahwa transaksi berlangsung dengan suatu pola tertentu yang cocok, kecuali bila bermaksud hendak mengakhiri kerjasama.

Dalam rangka memenuhi keperluan tersebut, Grice (1991) mengemukkan PKS yang berbunyi "Buatlah sumbangan percakapan Anda seperti yang diinginkan pada saat berbicara, berdasarkan tujuan percakapan yang disepakati atau arah percakapan yang sedang Anda ikuti”. PKS terdiri dari empat maksim, yakni (1) maksim kuantitas, (2) maksim kualitas, (3) maksim hubungan, dan (4) maksim cara. Masing-masing maksim memiliki submaksim sebagai berikut:

(1) Maksim kuantitas: Berilah jumlah informasi yang tepat dan diperlukan.

a. Buatlah sumbangan Anda seinformatif yang diperlukan.

b. Jangan membuat sumbangan Anda lebih informatif dari yang diperlukan.

(2) Maksim kualitas: Buatlah sumbangan atau kontribusi Anda sebagai sesuatu yang benar.

a. Jangan mengatakan apa yang Anda yakini salah. b. Jangan mengatakan sesuatu yang Anda tidak memiliki bukti.

(3) Maksim hubungan: Jagalah kerelevansian.

Bicaralah yang relevan.

(4) Maksim cara: Tajamkanlah pikiran.

a. Hindari ungkapan yang membingungkan.

b. Hindari ambiguitas.

c. Bicaralah secara singkat.

d. Bicaralah secara teratur.

Dalam sebuah interaaksi, pelanggaran maksim tutur sering tak terelakkan. Pelanggaran tersebut ada yang tidak sengaja dan ada yang disengaja. Grice (1975: 49) membedakan pelanggaran maksim tutur menjadi empat jenis, yaitu (1) violasi, (2) pengabaian, (3) perbenturan, dan (4) permainan. Violasi maksim tutur merupakan pelanggaran yang terjadi karena penutur tidak mampu menggunakan maksim tutur dengan benar. Pengabaian maksim tutur terjadi karena penutur enggan bekerjasama dengan mitra tutur. Perbenturan terjadi jika penutur berhadapan dengan pilihan penggunaan maksim tutur yang saling bertentangan, misalnya maksim kuantitas dengan maksim kesantuan. Permainan terjadi jika penutur sengaja melanggar maksim tutur dengan maksud agar tuturannya dipahami dengan lebih baik. Tiga jenis pelanggaran pertama disebut sebagai kegagalan dalam penggunaan maksim tutur (unintentional failure), sedangkan pelanggaran jenis keempat disebut pengintensifan (intention nonfulfilment).

Realisasi PKS memiliki dua bentuk, yakni bentuk menaati maksim PKS dan bentuk melanggar maksim PKS. Realisasi PKS memiliki fungsi beragam sesuai konteks penggunaannya. Misalnya, realisasi PKS di sidang pengadilan memiliki fungsi yang berbeda dengan realisasi PKS dalam interaksi kelas atau interaksi keluarga. Hal ini senada dengan pendapat Leech (1993:12) bahwa maksim-maksim PKS (1) berlaku secara berbeda dalam konteks penggunaan yang berbeda, (2) berlaku dalam tindakan yang berbeda; tidak ada prinsip yang berlaku secara 
mutlak, atau tidak berlaku sama sekali, (3) dapat berlawanan satu dengan yang lain, dan (4) dapat dilanggar tanpa meniadakan jenis tindakan yang dikendalikannya.

\section{PENAATAN PKS DAN FUNGSINYA}

\section{Penaatan Maksim Kuantitas}

Maksim kuantitas PKS menyarankan agar para pserta tutur dalam interaksi (a) memberi informasi seinformatif yang diperlukan, dan (b) tidak memberikan sumbangan informasi yang lebih dari yang diperlukan. Dalam realisasinya, peserta tutur dalam sebuah interaksi menaati maksim kuantitas dengan cara (a) menyampaikan tuturan berisi informasi yang tidak kurang dan tidak lebih, dan (b) menyampaikan tuturan yang berisi informasi yang tuntas atau sesuai yang dibutuhkan. Cara pertama biasanya digunakan untuk merespon tuturan yang memerlukan jawaban 'ya' atau 'tidak', jumlah, identitas, waktu, dan lokasi. Sedangkan cara kedua umumnya digunakan untuk merespon tuturan yang berisi pertanyaan 'bagaimana' dan 'mengapa'.

Arifin (1997) menemukan bahwa dalam interaksi sidang di pengadilan, para peserta tutur telah menaati maksim-maksim PKS, meskipun ada juga pelanggaranpelanggaran PKS. Namun, pelanggaran tersebut umumnya disengaja untuk mendayagunakan fungsi tuturannya. Jumadi (2001) menemukan hal sama bahwa para peserta tutur dalam interaksi sidang di pengadilan (hakim, jaksa penuntut, terdakwa, dan penasihat hukum) telah menaati maksimmaksim PKS. Meskipun terkadang memberikan informasi yang berlebihan, namun tidak disikapi sebagai pelanggaran maksim kuantitas karena dalam peristiwa tutur di pengadilan pengulangan informasi dianggap hal yang lumrah, bahkan seringkali merupakan keharusan untuk memperjelas informasi. Namun, dalam interaksi antarmahasiswa di kampus sebagaimana dikemukakan oleh Jazeri (2003), informasi berlebihan yang diberikan peserta tutur disikapi sebagai pelanggaran maksim kuantitas. Satu hal yang harus diperhatikan dalam hal ini adalah bahwa kuanitas informasi yang dibutuhkan oleh inisiasi pertanyaan berjenis "yes-no question" tentu tidak sama dengan kuantitas informasi yang dikehendaki inisiasi pertanyaan berjenis "wh-question".

Perhatikan contoh wacana berikut ini:

[1] A : Apa judul tugas analisis wacana Sampeyan?(1)

B : "Penggunaan Bahasa Indonesia dalam Wacana Politik di Media Massa".

(2)

B : Menggunakan analisis wacana kritis (AWK) siapa? (3)

\section{A : Fairclough. (4)}

Pada wacana [1] B menyampaikan informasi sesuai yang diminta oleh A. inisiasi A dengan tuturan (1) dan (3) direspon dengan informasi yang ditandai oleh $\mathrm{B}$ dengan tuturan (2) dan (4). Dengan demikian, dapat dikatakan bahwa dalam wacana [1] para peserta tutur telah menaati maksim kuantitas, yakni submasksim pertama. Para peserta tutur dalam sebuah interaksi menaati maksim kuantitas dengan tujuan sehingga informasi yang disampaikan dapat dipahami oleh mitra tuturnya dengan jelas agar tidak terjadi salah paham.

Dalam sebuah interaaksi, para peserta juga menaati maksim kuantitas submaksim kedua, yakni tidak memberikan informasi yang lebih dari yang dibutuhkan. Dalam realisasinya, hal tersebut terjadi apabila penutur merespon inisiasi yang berupa pertanyaan "bagaimana" dan "mengapa". Perhatikan wacana berikut.

[2] A : Mengapa Anda belajar Bahasa Inggris? (5)

B : Karena jika menguasai Bahasa Inggris, saya akan mampu berkomunikasi dengan orang asing, memahami bukubuku berbahasa Inggris, dan lebih mudah mendapat pekerjaan. (6)

Pada wacana [2] di atas, inisiasi A dengan tuturan (5) direspon dengan informasi yang memadai dalam tuturan (6). Karena inisiasi berupa pertanyaan "mengapa", maka 
respon yang diberikan lebih panjang dibanding respon terhadap inisiasi "apa" atau "siapa". Dengan demikian dapat dikatan bahwa pada wacana [2], para peserta tutur telah menaati maksim kuantitas, submaksim kedua.

Dari uraian di atas, dapat disimpulkan bahwa penaatan maksim kuantitas dalam sebuah interaksi berfungsi untuk (1) menyampaikan informasi yang jelas, (2) meminta bantuan, dan (3) menghindari kesalahpahaman. Singkatnya, penaatan maksim kuantitas dilakukan peserta tutur agar interaksi yang diikuti berlangsung dengan lancar dan sampai pada tujuannya.

\section{Penaatan Maksim Kualitas}

Maksim kualitas menyarankan agar peserta tutur dalam suatu interaksi (1) tidak memberikan informasi yang diyakini salah (bohong), dan (2) tidak memberikan informasi yang tidak didukung cukup bukti. Hal tersebut terwujud jka para peserta tutur memberikan sumbangan informasi yang diyakini benar, dan apa yang diinformasikan didukung oleh bukti yang memadai. Kebenaran yang dimaksud dapat berupa kebenaran faktual, kebenaran proporsional, dan kebenaran spiritual.

Untuk menentukan kebenaran suatu informasi tidaklah mudah. Dalam realisasinya, hakikat kebenaran dan ketidakbenaran suatu informasi, kebongan dan kejujuran seseorang, yang paling tahu adalah orang yang bersangkutan. Karena tidak mungkin kita melihat apa yang ada di balik benak para peserta tutur, Stubbs (1983) menyarankan agar kita bertumpu pada kebenaran faktual, yakni kebenaran yang didasarkan pada fakta. Kebenaran proporsional merupakan kebenaran yang didasarkan pada prinsip logika yang benar. Sedangkan kebenaran spiritual merupakan kebenaran yang didasarkan pada keyakinan spiritual yang biasanya disadari secara umum. Wacana berikut patut diperhatikan:

[3] G : Andi, kamu sudah mengerjakan tugas? (7)

$$
\text { A : Sudah, pak! (8) }
$$

G : Apa kamu punya kesulitan? (9)

A : (soal) Nomor 4, pak. (10)

G: Coba, bapak lihat! (11)

A : Ini, pak. (12)

Pada wacana [3] di atas, Andi telah memberikan informasi yang benar kepada gurunya. Kebenaran informasi yang disampaikan Andi dapat dilihat dari koherensi tuturan-tuturannya. Pada tuturan (8) Andi menyatakan bahwa ia telah mengerjakan tugas. Hal ini didukung oleh pengetahuannya tentang soal yang sulit (tuturan 10) dan dibuktikan dengan hasil kerjanya (tuturan 12). Dengan demikian dapat dikatakan bahwa Andi telah menaati maksim kualitas, submaksim pertama.

Wacana berikut merupakan contoh kebenaran spiritual yang digunakan terdakwa dalam sidang di pengadilan:

[4] P : Apa benar Saudara terdakwa mencuri kotak amal di masjid? (13)

T: Tidak pak. (14)

$\mathrm{P}$ : Saksi mengatakan Saudara yang mengambil, benar? (15)

$\mathrm{T}$ : Sumpah, tidak saya pak. (16)

Dalam wacana [4] di atas, terdakwa mneyampaikan informasi yang benar, yaitu dia tidak mencuri kotak amal masjid (tuturan 14). Ketika kebenaran informasinya disangsikan oleh penuntut, ia menyampaikan kebenaran spiritual, yakni bersumpah (tuturan 16). Hal ini dilakukan agar penuntut mengakui bahwa informasi yang disampaikannya benar. Dengan demikian dapat dikatakan bahwa penaatan maksim kualitas dalam sebuah interaksi berfungsi untuk (1) menyampaikan informasi yang benar, dan (2) mempertahankan pendapat (kebenaran).

\section{Penaatan Maksim Hubungan}

Maksim hubungan menyarakan agar para peserta tutur memberikan informasi yang relevan dengan topik pembicaraan. Dalam realisasinya, para peserta tutur dalam sebuah interaksi menaati maksim hubungan dengan 
cara menyampaikan tuturan yang berisi informasi yang relevan dengan alur interaksi yang sedang diikuti. Wacana interaksi di pengadilan berikut patut diperhatikan:

[5] H:Nama? (17)

$\mathrm{S}:$ Suparmin. (18)

$\mathrm{H}$ :Alamat? (19)

S : Sawojajar, Malang. (20)

$\mathrm{H}$ : Pekerjaan? (21)

S : Swasta. (22)

Pada wacana [5] tersebut, saksi (S) memberikan informasi yang relevan dengan inisiasi yang diberikan oleh hakim $(\mathrm{H})$. tuturan S (18), (20), dan (22) selalu relevan dengan inisiasi H (17), (19), dan (21). Dengan demikian dapat dikatakan bahwa $\mathrm{S}$ telah menaati maksim hubungan.

Relevansi suatu tuturan dilihat dalam kerangka hubungan yang lebih luas, yakni memiliki relevansi dengan konteks yang sedang terjadi meskipun secara literal tidak menunjukkan hubungan. Wacana interaksi antara penjual sate dan pembeli berikut patut diperhatikan:

[6] Pj : Kambing apa ayam, pak? (23)

$\mathrm{Pb}$ : Kambing sepuluh, pak. (24)

$\mathrm{Pj}$ : Kecap apa kacang? (25)

$\mathrm{Pb}$ : Kacang. Jangan pedes! (26)

Dalam wacana [6] di atas, secara literal informasi yang diberikan $\mathrm{Pb}$ kepada $\mathrm{Pj}$ tidak berhubungan. Namun dalam konteks memberli sate, informasi yang diberikan $\mathrm{Pb}$ melalui tuturan (24) dan (26) memiliki relevansi dengan inisiasi Pj mealui tuturan (23) dan (25). Karena para peserta tutur memiliki praanggapan yang sama, maka inisiasi yang diajukan $\mathrm{Pj}$ dan respon yang diberikan $\mathrm{Pb}$ memiliki relevansi. Karena itu, dapat dikatakan bahwa $\mathrm{Pb}$ telah menaati maksim hubungan.

Secara umum, penaatan maksim hubungan dalam sebuah interaksi berfungsi untuk membuat setiap tuturan yang disampaikan memberi informasi yang relevan dengan tuturan yang direspon dan situasi ujarnya. Secara khusus, penaatan maksim hubungan memiliki fungsi untuk (1) mengusut kebenaran informasi, (2) mencari informasi, dan (3) memberikan informasi yang benar.

\section{Penaatan Maksim Cara}

Maksim cara memiliki empat submaksim, yaitu (1) hindarilah ungkapan yang kabur, (2) hindarilah kata-kata yang berarti ganda, (3) berbicaralah dengan singkat, dan (4) berbicaralah dengan teratur. Dalam realisasinya, peserta tutur dalam sebuah interaksi menaati maksim cara dengan cara menghindari tuturan yang kabur, menghindari tuturan yang berarti ganda, tidak berbelit-belit, dan menyampaikan tuturan secara teratur. Biasanya, tuturan yang menaati maksim kuantitas sekaligus juga menaati maksim cara. Perhatikan wacana berikut:

[7] A : Berapa (hasil akhir) Chelsea lawan Liverpool? (27)

B : Tiga, satu. (28)

A: Di final, kamu pegang mana? (29)

B : MU (Manchester United). (30)

Pada wacana [7] di atas, B memberikan informasi yang dibutuhkan oleh A. Wacana di atas memiliki konteks semifinal liga Champion antara Chealsea melawan Liverpool. Tuturan (28) memberikan informasi skor akhir pertandingan semi final antara Chelsea melawan Liverpool, sedangkan tuturan (30) memberikan informasi tentang tim favorit juaran, karena sebelumnya MU telah menang melawan Barcelona 1-0. Karena itu dapat dikatakan bahwa B telah menaati maksim cara.

Secara umum, penaatan maksim cara dalam sebuah interaksi memiliki fungsi untuk menyampaikan informasi secara jelas, tidak ambigu, singkat dan teratur dalam rangka menunjang tercapainya tujuan interaksi yang sedang diikuti. Secara khusus, penaatan maksimcara berfungsi untuk (1) menyampaikan informasi yang singkat dan jelas, dan (2) menghindari kesalahpahaman. 


\section{E. PELA N G GARAN PKS DAN FUNGSINYA}

\section{Pelanggaran Maksim Kuantitas}

Berdasarkan hasil beberapa penelitian diketahui bahwa dalam sebuah interaksi sering terjadi pelanggaran maksim kuantitas. Pelanggaran ini terjadi baik pada submaksim pertama (memberikan sumbangan informasi seinformatif yang dibutuhkan) maupun submaksim kedua (tidak memberikan informasi yang lebih dari yang diperlukan). Pelanggaran tersebut ada yang tidak sengaja, dan ada yang memang disengaja.

Pelanggaran maksim kuantitas dalam intraksi memiliki fungsi (1) mengkaburkan informasi, (2) berlaku sopan, (3) memperjelas informasi, dan (4) memunculkan implikatur percakapan. Fungsi (1) biasanya terjadi apabila mitra tutur hanya memberikan informasi yang terlalu sedikit atau kurang. Fungsi (2) biasanya terjadi pada interaksi informal, terutama masyarakat Jawa. Penelitian Wiryotinoyo (1996) membuktikan bahwa masyarakat tutur Jawa lebih suka memberikan informasi lebih agar dinilai sopan daripada berbicara seperlunya. Fungsi (3) biasanya terjadi apabila peserta tutur memberikan informasi yang lebih dari yang dikehendaki mitra tuturnya. Perhatikan contoh wacana berikut:

[8] A. Dari mana mas? (31)

B. Dari pasar, membeli makanan lele. Harganya naik lagi. (32)

Wacana [8] tersebut merupakan contoh fungsi (2) dan (3), yaitu untuk berlaku sopan dan memperjelas informasi. Dalam wacana [8], A sebenarnya hanya membutuhkan informasi dari pasar. Namun B memberikan informasi yang lebih dari yang dibutuhkan A. Ditinjau dari PKS, B telah melanggar Maksim kuantitas, khususnya submaksim kedua, yakni jangan memberikan sumbangan informasi yang melebihi dari yang diperlukan. Pelanggaran yang dilakukan $\mathrm{B}$ berfungsi memperjelas informasi, yaitu informasi tentang harga pakan lele yang semakin mahal.

Dalam interaksi antara bapak dan anak berikut ini juga melanggar maksim kuantitas.
Namun pelangaran tersebut dimaksudkan untuk memunculkan implikatur percakapan.

[9] A. Paak....! (33)

B. Ya, ada apa dik? (34)

A. Paak...! (35)

B. Susu? (36)

A. (mengangguk).

Pada wacana [6] di atas, A tidak memberikan informasi yang cukup kepada B, sehingga B sulit menafsirkan maksud tuturan A. Setelah B menanyakan 'susu?' dan A 'mengangguk' baru diketahui bahwa tuturan A 'Paak...!' dimaksudkan untuk memunculkan implikatur 'Pak, minta susu'.

\section{Pelanggaran Maksim Kualitas}

Di samping pelanggaran terhadap maksim kuantitas, para peserta interaksi juga melanggar maksim kualitas baik submaksim pertama (tidak memberikan informasi yang diyakini salah) maupun submaksim kedua (tidak memberikan informasi yang tidak didukung oleh bukti yang cukup). Pelanggaran maksim kualitas submaksim pertama terkadang sengaja dilakukan oleh peserta tutur karena ingin menimbulkan kelucuan dan canda dalam rangka untuk mencairkan suasana yang formal dan kaku. Pelanggaran maksim kualitas submaksim pertama ini juga dilakukan untuk menutupi informasi yang sebanarnya agar tujuannya tidak diketahui oleh mitra tuturnya. Pelanggaran maksim ini juga terkadang disengaja untuk memunculkan implikatur percakapan, yakni makna dibalik yang diungkapkan. Bahkan ada juga yang sengaja melanggar maksim kualitas untuk mengejek orang lain. Perhatikan wacana interaksi antarmahasiswa berikut:

[10] Aty : Sebenarnya kalau kita mau sungguhsungguh, (kuliah) di mana saja sih nggak masalah. (37)

Yeni : Kayak mbak Ati gini. (sambil main mata dengan Bibah dan Nisa'). (38)

Bibah : Nggak pernah keluar-keluar, nggak pernah pulang. (39)

Nisa' : Nggak kenal cowok. (40) 
Fungsi untuk mengejek dapat dilihat wacana [10]. Dalam wacana tersebut tuturan Yeni kaya mbak Ati gini, tuturan Bibah Nggak pernah keluar-keluar, nggak pernah pulang, dan tuturan Nisa Nggak kenal cowok adalah tidak sesuai dengan kenyataan. Konteks wacana [10] Ati adalah teman satu kos mereka yang suka jalan-jalan, nonton TV, dan kenal dengan cowok. Berdasarkan hal tersebut dapat dipahami bahwa Yeni, Bibah, dan Nisa melakukan pelanggaran maksim kualitas, terutama submaksim pertama, dengan sengaja (mempermainkan maksim tutur). Tujuannya jelas, yaitu untuk mengejek Ati yang dianggapnya sok alim.

\section{Pelanggaran Maksim Hubungan}

Dalam sebuah interaksi, peserta tutur diharapkan memberikan informasi yang dengan topik pembicaraan. Informasi yang diberikan hendaknya menunjang terwujudnya tujuan pembicaraan atau arah pembicaraan yang sedang diikuti. Jika menyimpang dari topik yang ada, maka suatu tuturan dianggap melanggar maksim hubungan. Pelanggaran maksim hubungan terkadang terjadi dalam sebuah interaksi karena maksud ingin mencairkan suasana dan membuat interaksi semakin akrab. Dalam mengakrabkan suasana, peserta tutur yang sebelumnya belum kenal terkadang sengaja melanggar maksim hubungan untuk memunculkan kesan lucu. Di samping itu, pelanggaran maksim hubungan juga dimaksudkan untuk memunculkan implikatur percakapan, yaitu makna tidak langsung dari apa yang dituturkan.

[11] A : Siapa namanya, mas? (41)

B : Ali. (42)

A : Boleh tahu, siapa guru Bahasa Inggris di sini? (43)

B : Sumpah, bukan saya. (44)

Pelanggaran yang dilakukan B dalam tuturan dapat dikatagorikan sebagai permainan maksim tutur. Hal ini sengaja dilakukan agar terjadi keakraban diantra peserta tutur yang baru saling mengenal. Pelanggaran semacam itu juga sering terjadi di dalam lawakan. Dalam dunia lawak, pelanggaran maksim hubungan sering sengaja dilakukan untuk memunculkan kesan lucu dari interaksi yang dilakukannya. Perhatikan wacana humor berikut ini.

[12] Babe : Sir, tolong pijitin babe, badan babe kagak enak! (45)

Nasir : Kalau enak mah sudah abis dibrakot orang. (46)

Babe : $L u$ memang paling pinter ngebaikbalikin! (47)

Nasir : Kalau nggak dibalik mah gosong. (48)

Babe : Pusing mikirin omongan $l u$ sir! (49)

Nasir : Kalau pusing, sono minum obat sakit kepala. (50)

Pada wacana [12], antara Babe dan Nasir melanggar maksim hubungan. Namun tentu dapat ditebak bahwa pelanggaran tersebut bukan karena Babe dan Nasir tidak mengetahui kaidah interaksi, melainkan disengaja agar para penonton mendapatkan kesan lucu dari interaksi yang mereka lakukan.

Di samping itu, pelanggaran maksim hubungan juga dimaksudkan untuk memunculkan implikatur percakapan, yaitu makna tidak langsung dari apa yang dituturkan.

[13] B : Mainannya bagus-bagus, Papa sudah gajian? (51)

A : Sekarang masih tanggal tua, dik? (52)

B : Nanti tanggal muda, beliin ya pa? 53)

A : Oke bos! (54)

Pada wacana [13], interaksi antara bapak dan anak melanggar maksim hubungan. Namun pelanggaran tersebut tampaknya disengaja untuk memunculkan implikatur percakapan. Tuturan F (51) "Papa sudah gajian" memiliki implikatur bahwa si anak ingin dibelikan mainan. Hal ini tentu berdasarkan praanggapan kebiasaan sang bapak yang seorang PNS selalu menjanjikan membelikan sesuatu kalau sudah gajian. Karena para peserta interaksi memiliki praanggapan yang sama, 
maka implikatur yang ingin disampaikan dapat dipahami dengan baik sehingga interaksi mencapai tujuannya.

\section{Pelanggaran Maksim Cara}

Pelanggaran maksim cara juga sering terjadi dalam sebuah interaksi, baik submaksim pertama (menghindari ungkapan yang kabur), submaksim kedua (menghindari kata-kata yang berarti ganda), submaksim ketiga (berbicara singkat), dan submaksim keempat (berbicara yang teratur). Umumnya, peserta tutur melanggar maksim cara dengan cara memberikan informasi yang berbelit-belit, tidak singkat, sehingga mitra tutur tidak mendapatkan informasi sebagaimana diinginkan.

Berdasarkan hasil beberapa penelitian ditemukan bahwa pelanggaran maksim cara dalam sebuah interaksi fungsi (1) menutupi malu atau menyelamatkan muka, (2) bercanda, dan (3) memunculkan implikatur percakapan. Perhatikan wacana berikut:

[14] N: Kamu ngasih apa sama mereka? (55)

Ye : Pertama, kita awalnya itu ngumpul di rayon. Gitu ya sama anak-anak diajakin. Sampai di sana ternyata anaknya pemulung di sana itu ada yang disunat. Ya ngak ngasih apa-apa. (56)

Pelanggaran yang dilakukan Yeni dalam wacana [11] dapat dikatagorikan sebagai pengabaian maksim tutur (opt out). Dikatakan demikian karena Yeni tampaknya sengaja menyampaikan tuturan yang berbelit-belit dan tidak langsung agar informasi yang disampaikan tidak dipahami dengan baik oleh Nisa. Yeni enggan memberikan informasi secara singkat karena dimotivsi oleh rasa malu jika diketahui oleh Nisa' bahwa dia berkunjung ke tempat pemulung tanpa memberi apa pun kepada mereka.

Fungsi memunculkan implikatur percakapan dapat dilihat pada wacana di bawah ini.

[15] A: Paak....!(57)

B : Ya, sudah sarapan dik? (58)
A: Paak...! (59)

B : Apa lagi? (60)

A : Paak... nanti ada les. (sambil menunjukkan uang saku Rp 2000 dari Ibu). (61)

B : Nih, Bapak tambah dua ribu. (62)

A : Terima kasih Pak. (sambil berangkat sekolah) (63)

Pada wacana [15] di atas, si Anak tidak hanya melanggar maksim kuantitas, tetapi juga melanggar maksim cara. Si anak tidak hanya memberikan sumbangan informasi yang tidak memadai (melanggar maksim kuantitas), tetapi juga menyampaikan informasi secara berbelitbelit (melanggar maksim cara). Dari konteks yang ada dapat dikatakan bahwa pelanggran tersebut merupakan permainan maksim tutur. Si anak hanya mengatakan "Paak...!" untuk meminta tambahan uang saku. Maksud tuturan si anak adalah "Pak minta tambahan uang saku". Untuk melakukan itu, si anak menggunakan tuturan tidak langsung, dengan cara menunjukkan uang saku dari ibu yang dirasa kurang karena ada les. Dengan tuturan (61) si anak berharap bapaknya mengerti apa yang ia inginkan (implikatur) tanpa harus menyatakannya secara eksplisit.

\section{F. PENUTUP}

Dalam sebuah interaksi, para peserta interaksi selain menaati prinsip kerjasama, tetapi juga melanggarnya. Penaatan dan pelanggaran maksim kerjasama tersebut dalam sebuah interaksi memiliki fungsi. Penaatan maksim kuantitas berfungsi untuk menyampaikan informasi dengan jelas, meminta bantuan, dan menghindari salah paham. Penaatan maksim kualitas berfungsi untuk menyampaikan informasi yang benar, mempertahankan pendapat, dan membuat kesimpulan. Penaatan maksim hubungan berfungsi untuk mengusut kebenaran informasi, mencari informasi, dan memberikan informasi. Penaatan maksim cara berfungsi untuk menyampaikan informasi dengan jelas dan menghindari kesalahpahaman. 
Pelanggaran PKS berserta maksimmaksimnya dalam sebuah interaksi dapat berupa violasi, pengabaian, perbenturan dan permainan. Di antara pelanggaran tersebut yang paling sering terjadi adalah perbenturan dan permainan. Pelanggaran PKS berserta maksimmaksimnya dalam interaksi memiliki beberapa fungsi. Pelanggaran maksim kuantitas berfungsi untuk mangaburkan informasi dan memperjelas informasi. Pelanggaran maksim kualitas berfungsi untuk menimbulkan kelucuan, menyembunyikan maksud, mengejek, dan menyelamatkan muka. Pelanggaran maksim hubungan berfungsi untuk menimbulkan implikatur percakapan, dan bercanda. Pelanggaran maksim cara berfungsi untuk menutupi malu atau menyelamatkan muka, bercanda, dan menimbulkan implikatur percakapan.

\section{DAFTAR PUSTAKA}

Allen, J.P.B. 1975. Paper in Applied Linguistics. Vol.II. London: Oxford University.

Arifin. Bustanul. 1997. Analisis Tanya Jawab dalam Peristiwa Tutur di Pengadilan. Tesis tidak Diterbitkan. Jakarta: PPS Universitas Indonesia.

Grice, H. Paul. 1975. Logic and Conversation. Dalam Peter Cole dan Jerry L. Morgan. (EDS). Syntax and Semantics Volume 3: Speech Acts. New York: Academic Press.

Grice, H. Paul. 1991. Logic and Conversation. Dalam Davis, S. (Ed). Pragmatics: A Reader. New York: Oxford University Press.

Hymes, Dell. 1973. Foundation in Sociolinguistics: an Ethnography Approach. Philadelphia: University of Pensylvania Press.
Ibrahim, Abd Syukur. 1993. Kajian Tindak Tutur. Surabaya: Usaha Nasional.

Jazeri. 2003. Realisasi Prinsip Kerjasama dalam Interaksi Antarmahasiswa. Tesis tidak diterbitkan. Malang: PPS UNISMA Malang.

Jumadi, 2001. Realisasi Prinsip Kerjasama dalam Interaksi Sidang di Pengadilan. Tesis tidak diterbitkan. Malang: PPS IKIP Malang.

Leech, Geoffrey. 1993. Prinsip-prinsip Pragmatik. Terjemahan M. D. D Oka. Jakarta: Universitas Indonesia Press.

Levinson, Stephen C. 1992. Pragmatics. Cambridge: Cambridge University Press.

Rofi'uddun, A. 1990. Studi tentang Bentuk dan Fungsi Pertanyaan dalam Interaksi Kelas Bahasa Indonesia dan dalam Interaksi dalam Keluarga. Tesis tidak diterbitkan. Malang: PPS IKIP Malang.

Searle, John R. 1969. Speech Acts: An Essay in the Philosophy of Language. Cambridge: Cambridge University Press.

Seville-Troike. 1982. The Ethnography of Communication. Oxford: Basil Blacwell.

Stubbs, Michael. 1983. Discourse Analysis: The Sociolinguistics Analysis of Natural Language. Chicago: The University of Chichago Press.

Wiryotinoyo. 1996. Implikatur Percakapan Anak Usia SD. Disertasi tidak diterbitkan. Malang: PPS IKIP Malang. 